\title{
BioDegradation of Refined Petroleum Hydrocarbons in Soil
}

\author{
*OBIRE, O.; NWAUBETA, O.
}

Department Of Biological Sciences, Rivers State University Of Science and Technology P. M. B. 5080 Port Harcourt Nigeria

\begin{abstract}
Carbon-dioxide production and hydrocarbon degradation of refined petroleum hydrocarbon in soils treated with $5 \%$ gasoline, kerosene and diesel oil were investigated. Soil for study was bulked from around a car park in Port Harcourt. Soil samples were collected at weekly intervals for four weeks and subsequently at monthly intervals for four months, between the months of March and July 1998. The volume of carbon-dioxide produced in $40 \mathrm{~g}$ soil ranged from $17.6 \mathrm{mg}$ to $105.6 \mathrm{mg}$ for the control soil and from $30.8 \mathrm{mg}$ to $154 \mathrm{mg}$ for the hydrocarbon-contaminated soils. Statistical analysis using paired t- test between control and hydrocarbon contaminated soils showed significant differences for gasoline - contaminated soils. The rate of hydrocarbon degradation ranged from $0 \mu \mathrm{gg}^{-1}$ oil h${ }^{-1}$ to $0.60 \mu \mathrm{gg}^{-1} \mathrm{oil} \mathrm{h}^{-1}$ for the control soil; $0.05 \mu \mathrm{gg}^{-1}$ gasoline $^{-1}$ to $1.67 \mu \mathrm{gg}^{-1}$ gasoline $\mathrm{h}^{-1}$ and from $0.12 \mu \mathrm{gg}^{-1}$ diesel oil $\mathrm{h}^{-1}$ to $1.31 \mathrm{ggg}^{-1}$ diesel oil $\mathrm{h}^{-1}$ for the hydrocarbon contaminated soils respectively. Carbondioxide production was generally higher in the hydrocarbon - contaminated soils than in the control soil with gasoline> diesel oil > control soils. @ JASEM
\end{abstract}

Petroleum production began in Nigeria in 1958 and since then, cases of petroleum and refined petroleum spills onto agricultural lands through petroleum production operations have been reported (Odu, 1977; Awobajo, 1981, Grevy, 1995, Moffat and Linden, 1995). The soil environment is the most dynamic site of interactions in nature and it is also the region in which many of the biochemical reactions concerned in the decomposition of organic matter and nutrition of plants particularly agricultural crops occur (Torstensson et al., 1998). The microbial community carries out the majority of decomposition processes in the soil and are irreplaceable in the transformation and degradation of synthetic organic compounds and natural waste materials (Atlas, 1991, Atlas and Bartha, 1992 Torstensson et al., 1998). During utilization of energy sources, complex organic materials are utilized, which results in the production/release of inorganic plant nutrients such as nitrogen, phosphorous and sulphur.

Intimate relationship exist between physicochemical properties of soil, soil organisms and soil biological properties. The use of microorganisms and their activities in tests of effects of a specific chemical substance in soil, as well as in studies of soil pollution has often been recommended.

The microbiological decontamination (bioremediation) of oil polluted soils is claimed to be an efficient, economic and versatile alternative to physico-chemical treatment (Atlas, 1991). Bioremediation involves the use of indigenous or introduced microorganisms to degrade environmental contaminants (Margesin and Schinner, 1997).

The rate of microbial degradation of hydrocarbons in soils is affected by several physicochemical and biological parameters including the number and species of microorganisms present, the conditions for microbial degradation activity (e.g. presence of nutrient, oxygen, $\mathrm{P}_{\mathrm{H}}$ and temperature) the quality, quantity and bioavailability of the contaminants; and the soil characteristics such as particle size distribution (Margesin and Schinner, 1997).

The population of microorganisms found in a polluted environment will degrade petroleum differently and at a different rate than microorganisms in a relatively clean environment (Obire and Okudo, 1997). Petroleum hydrocarbon utilizing bacteria can tolerate oil - contaminated environments because they possess the capability to utilize oil as energy sources (Song et $\underline{\text { al. }}$, 1990). Other species may not and are gradually eliminated.

Microbial decomposition of petroleum and petroleum products is of considerable importance. Petroleum is a rich, source of carbon and the hydrocarbon within it are readily oxidized aerobically with the release of carbon-dioxide by a variety of microorganisms in soil (Odu, 1977; Atlas, 1981, Atlas and Bartha, 1992; Steffan et al, 1997).

Although there is considerable information as to the microbial utilization of mixtures of chemically defined hydrocarbons and crude oils, (Obire 1990, 1993, Steffan et al 1997).

There are no studies concerned with a comparison of the effect of refined petroleum hydrocarbons on soil respiration rate.

The aims of this study were to investigate the effect of refined petroleum on soil metabolic rate and on the rate of hydrocarbon degradation in the soil. This was carried out by comparing the effect of gasoline, kerosene and diesel oil on $\mathrm{CO}_{2}$ production in the soil and on the changes at the concentration of the refined petroleum in soil.

* Corresponding author 


\section{MATERIALS AND METHODS}

The soil used for this study is a petroleum hydrocarbon contaminated soil bulked from around a car park in Port Harcourt. A scoop was used to remove debris of organic particles from the surface of the soil. Surface soil ( 0 to $15 \mathrm{~cm})$ was collected at random, bulked, air dried and passed through a $2 \mathrm{~mm}$ sieve ( Jepson Bolton \& Co. Ltd., Watford U.K.) and stored in a green house.

Petroleum hydrocarbon fractions (gasoline, kerosene and diesel oil) were collected from the storage tanks of Total Petroleum Marketing Company. Prior to collection of the petroleum hydrocarbons, the outlet of the pumps were flushed severally before collection into sterile containers. The petroleum hydrocarbon treatment were applied at $0 \%$ and $5 \%$ levels.

Carbondioxide production in incubated soils were determined by Comfield (1961) method. Petroleum hydrocarbon treated soil samples (40g) were placed in screw capped bottles in triplicates, followed by placement of vials containing $0.5 \mathrm{~g}$ of barium peroxide solution (dissolved in the ratio $1: 10(\mathrm{v} / \mathrm{w})$ by adding $5 \mathrm{ml}$ of distilled water to $0.5 \mathrm{~g}$ of barium peroxide contained in small vials). Barium peroxide vials were also placed in two empty screw capped bottles to serve as control.

The soil samples were incubated at room temperature $\left(28^{\circ} \mathrm{C}\right)$ after screwing tight the bottles. Each bubble tower formed due to the absorption of $\mathrm{CO}_{2}$ was rinsed with $20 \mathrm{ml}$ of distilled water and put into a conical flask for titration. Few drops of phenolphthalein indicator were added to the solution and the un-neutralized base $\left(\mathrm{BaCO}_{3}\right)$ formed is titrated with $1 \mathrm{~N}$ hydrochloric acid.

The residual hydrocarbon remaining in the soil after incubation period was determined according to the method described by Odu et al., (1985). The hydrocarbon content of the soils were determined by shaking $5 \mathrm{~g}$ of a representative soil sample with $10 \mathrm{ml}$ of toluene. The hydrocarbon content extracted was determined by the absorbance of the extract at $420 \mathrm{~nm}$ in a spectronic 20 spectrophotometer. A standard curve of the absorbance of known concentrations of the different petroleum hydrocarbon fractions in extractant was first drawn from which the quantity of hydrocarbon remaining and hydrocarbon degraded was calculated. The rate of hydrocarbon degraded was also calculated from the quantity of hydrocarbon degraded.

\section{RESULTS AND DISCUSSION}

Values of cabondioxide produced in $40 \mathrm{~g}$ of the control soil ranged from $17.6 \mathrm{mg}$ to $105.6 \mathrm{mg}$ while values for gasoline, kerosene and diesel oil contaminated soils ranged from $79.2 \mathrm{mg}$ to $154 \mathrm{mg}$; $52.8 \mathrm{mg}$ to $145.2 \mathrm{mg}$ and from $30.8 \mathrm{mg}$ to $90.2 \mathrm{mg}$ respectively.

Apart from the 4th, 12th and 16th weeks, when $\mathrm{CO}_{2}$ produced in the control soil was higher than $\mathrm{CO}_{2}$ produced in the diesel oil and kerosene (12th week) contaminated soils, $\mathrm{CO}_{2}$ production was generally higher in the hydrocarbon contaminated soils than in the control soil in which $\mathrm{CO}_{2}$ production was lower.te of hydrocarbon - degradation ( $\mu \mathrm{g}$ oil $\mathrm{h}^{-}$ $\left.{ }^{1}\right) *$ in the petroleum contaminated soils is as shown in table 1.

Table 1: Rate of hydrocarbon - degradation $\left(\mu \mathrm{g}_{\text {oil }} \mathrm{h}^{-1}\right) *$ in the petroleum contaminated soils.

\begin{tabular}{|l|l|l|l|}
\hline $\begin{array}{l}\text { Treatment } \\
\text { /Period }\end{array}$ & Control & Gasoline & $\begin{array}{l}\text { Diesel } \\
\text { Oil }\end{array}$ \\
\hline $\mathrm{W}_{1}$ & 0 & 0.05 & 0.12 \\
\hline $\mathrm{W}_{2}$ & 0.12 & 0.60 & 0.28 \\
\hline $\mathrm{W}_{3}$ & 0.24 & 1.13 & 0.42 \\
\hline $\mathrm{W}_{4}$ & 0.60 & 1.67 & 1.31 \\
\hline $\mathrm{W}_{8}$ & 0.14 & 0.68 & 0.61 \\
\hline $\mathrm{W}_{12}$ & 0.36 & 0.95 & 0.91 \\
\hline $\mathrm{W}_{16}$ & 0.36 & 0.95 & 0.91 \\
\hline TOTAL & 1.82 & 6.03 & 4.56 \\
\hline MEAN & 0.26 & 0.86 & 0.65 \\
\hline
\end{tabular}

* Values are means of three replicates

Carbondioxide production in the hydrocarbon contaminated soils are as shown in fig 1 . There was a progressive increase in the amount of carbon-dioxide produced for the first four weeks in the hydrocarbon contaminated soils, after which carbon-dioxide production decreased. Large amounts of carbon-dioxide were liberated in the hydrocarbon contaminated soils than in the control soil. The progressive increase in the amount of carbon-dioxide evolved in the incubated soils in the first four weeks is an indication of the utilization of petroleum hydrocarbon fractions as a source of carbon and energy by the microbial community.

The end-product of petroleum hydrocarbon degradation are carbon-dioxide and water which are also measures of microbial respiration and activity in soils. Higher rates of biodegradaton by soil microbial activity as shown from the carbon-dioxide production occurred during the first four weeks, the increase in carbon-dioxide production was progressive initially but started decreasing after week 4 . This is also collaborated by the rates of biodegradation which was highest in the first four weeks. See table 1 


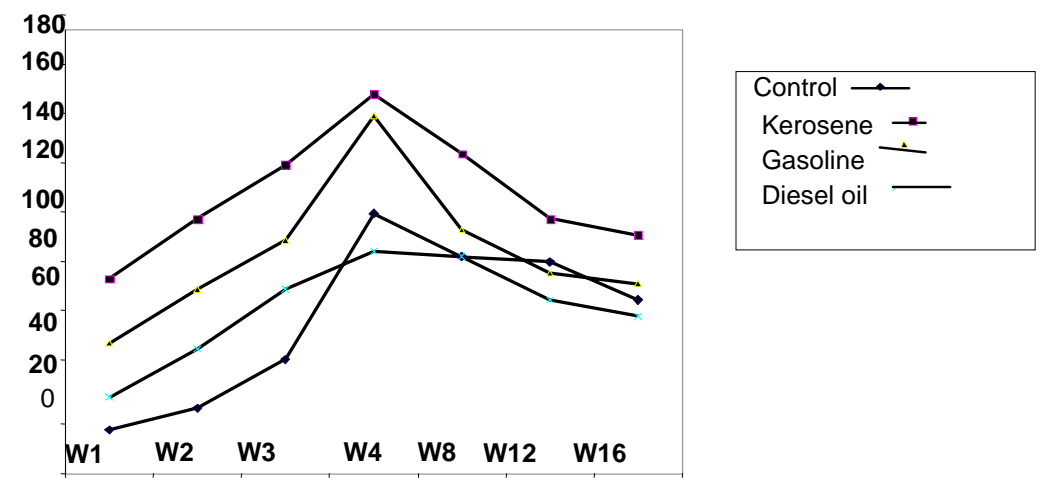

Fig. 1 Effects Of Refined Hydrocarbons On Carbon dioxide Production* In Soils

The amount of carbondioxide produced in the control and in the hydrocarbon contaminated soil is in the order of Gasoline $>$ Kerosene $>$ Control $>$ Diesel oil. Respiration of microbes occurred very rapidly during the initial period of incubation when the lighter and more readily degraded fractions were degraded but slowed down as the residue became more difficult to degrade on account of the increase of the heavier fractions.

The rate of hydrocarbon degradation was highest in the first four weeks, after which the rate declined in the control and hydrocarbon contaminated soils. Rate of biodegradation was in the order of Gasoline > Diesel oil > Control

Unfortunately the spectrophometer was unable to analyze for the kerosene - treated samples.

\section{CONCLUSION}

Carbon-dioxide production which is a measure of microbial activity and respiration occurred in all soils. This confirms the fact that the microorganisms metabolized the petroleum hydrocarbons, which resulted in a progressive increase in carbon dioxide evolved, which decreased later following exhaustion of metalizable fractions.

The indigenous microbial flora of that soil showed hydrocarbon degradation potentials as was revealed by total hydrocarbon data obtained and carbon-dioxide production in the soils.

There was significant difference between control soil and gasoline - contaminated soil at both $5 \%$ and $1 \%$ level of probability.

\section{REFERENCES}

Atlas,. R. M., 1981. Microbial Degradation of Petroleum Hydrocarbons: an Environmental Perspective Microbiol Rev. 45: 180 -209

Atlas, R. M. 1991. Microbial Hydrocarbon Degradation - Bioremediation of oil spills J. Chem. Technol - Biotechenol 52: 149 - 156.

Atlas, R. M. and R, Bartha, 1992. Hydrocabon Biodegradation and Oil Spill Bioremediation Adv. Microb. Ecol._ 12: 287 - 338.

Awobajo, A. O. (1981). An Analysis Of Oil Spill Incidents in Nigeria. Proceedings of National Seminar on Petroleum Industries and Nigerian Environment, Warri pp. 57 - 63

Cornfield, A. H. 1961. A simple Technique for Determining Mineralization of Carbon during Incubation of soil treated with Organic material Plant and Soil 14: 90 - 93.

Grevy, P. (1995). The Niger Delta Nigeria Pollution Assessment Study. Report to the World Bank. Carl Bro International Glostrup Denmark. Pp 125.

Lyle, G. W., L. Bourbonniere, and Charles, W. G., 1997. Biodegradation of Petroleum Hydrocarbons by Pschrotrophic Pseudomonas strains possessing both alkanes (alk) and 
Naphthalene (nah) Catabolic pathways Appl. Environ. Microbiol.

Margesin, R. and F. Schinner, 1997. Efficiency of Indigenous and Inoculated cold-adapted soil Micro-organisms for Biodegradation of Diesel Oil in Alphine soils. Appl. Environ. Microbial 67(7): 2660 - 2664.

Moffat, D. and O. Linden, 1995. Perception and Reality: Assessing Priorities for Sustainable Development in the Niger River Delta. Ambio. 24 (7-8): 527 - 532.

Obire, O. (1990). Bacterial Degradation of three Different crude oils in Nigeria. Nig. J. Bot. 1: 81-90.

Obire, O. (1993). The Suitability of Various Nigerian Petroleum Fractions as Substrate for Bacterial Growth. _Discov. Innov. 9: 25-32.

Obire, O. and I. V. Okudo, 1997. Effects of Crude Oil on a Freshwater Stream in Nigeria. Discov. Innov. $925-32$.
Odu, C. T. I 1977. Pollution and the Environment. Bull. Sci. Assoc. Nig. 3(2) : $284-285$

Odu, C. T. I., O. F. Esuruoso, L.C. Nwoboshi and J. A. Ogunwale, 1985. Environmental Study of the Nig. Agip Oil Company, Operational Area. Soil and Fresh Water Vegetation. Union Graft publs. Milan PP. $22-25$

Song, H. X. Wang, and R. Bartha, 1990. Appl. Environ Microbiol. 56: 652.

Steffan, R. J, K. Mccloy, S. Vainberg, C. W. Condee, and D. Zhang, 1997. Biodegradation of the Gasoline Oxygenates Methyle tert-Butyl Ether, Ethyl tert-Butyl Ether and tert - Amyl Methyl Ether by Propane-Oxidizing Bacteria. Appl. Environ. Microbiol. 63(11): 4216-4222.

Torstensson. L, Mikael Pell and Bo Stenberg, 1998. Need of a strategy for Evaluation of Arable Soil Quality AMBIO Vol. 27 No. 1. Royal Swedish Academy of Sciences. pp. $4-7$. 